\title{
O estatuto da emoção em Esquisse d'une théorie des émotions ${ }^{22}$
}

\author{
The emotion's status in the Esquisse d'une \\ théorie des émotions
}

Gustavo Fujiwara

Pós-doutorando em Filosofia pela UFSCAR

\begin{abstract}
Resumo: O objetivo deste artigo é o de investigar a maneira pela qual o filósofo francês Jean-Paul Sartre, a partir de sua definição de psicologia fenomenológica, compreende a consciência emotiva e seu correlato, a emoção. Ver-se-á, portanto, que esta psicologia fenomenológica será definida por Sartre - a partir da influência que Husserl exerce sobre seu pensamento - como psicologia eidética. Nesta toada, a investigação psicofenomenológica da emoção deverá proceder a partir de uma análise eidética cujo objetivo será o de desvelar a essência (eidos) da consciência emotiva. Daí a questão eidética essencial: o que deve ser uma consciência para que a emoção seja possível? Reatualizando a psicologia a partir da fenomenologia (isto é, a partir da definição de consciência intencional - toda consciência é consciência de...), Sartre fornece uma teoria acerca da emoção completamente diferente das teorias clássicas de seu tempo.
\end{abstract}

Palavras-chave: Fenomenologia; Psicologia Fenomenológica; Emoção; Consciência; Corpo.

O presente artigo deriva de nossa dissertação de mestrado financiada pela CAPES. 
Abtract: The aim of the present article is to investigate the way how the French philosopher Jean-Paul Sartre, through his definition of phenomenological psychology, comprises the emotive consciousness and its correlate, the emotion. It will be seen, then, that this phenomenological psychology will be defined by Sartre - from the influence that Husserl exerts under his thought - as eidetic psychology. In this task, the psycho-phenomenological investigation of emotion must proceed from an eidetic analysis whose objective will be to unveil the essence (eidos) of the emotive consciousness. So the essential eidetic question: what must be a consciousness so that emotion is possible? By restating psychology from phenomenology (that is, from the definition of intentional consciousness - all consciousness is consciousness of ...), Sartre provides a theory of emotion completely different from classical theories of his period.

Keywords: Phenomenologie; Phenomenological Psychology; Emotion; Consciousness; Body.

\section{O projeto da psicologia fenomenológica em Esquis- se: o empírico e o transcendental}

Dublicado nos anos de 1939, Esquisse d'une théorie des émoLions é o único testemunho maior da obra inacabada La Psyché, figurando como sua introdução. Nesta obra, Sartre pretenderá promover uma concepção eidética e existencial do fenômeno emoção. Para tanto, ele deverá examinar as teorias psicológicas clássicas a lume da pela polaridade conceitual Husserl $\backslash$ Heidegger até chegar ao esboço de uma psicologia tornada eidética; logo, é questão observar se a psicologia da qual fala Sartre pode aproveitar o método e os ensinamentos que dispõe a fenomenologia. A consciência,outrora esquadrinhada por La transcendance de l'Ego (1937),deverá, doravante, contar com uma nova variação eidética (a emoção) e o conceito de psíquico tramar-se-á a partir do conceito fundamental de essência (eidos). Por conseguinte, aquela região não-fenomenológica representada pelo psíquico no ensaio sobre o ego transcendente passará aqui ao plano da essência da consciência dada a entrada do conceito de realidade-humana (tradução francesa do Dasein heideggeriano). 
Sendo assim, nossas exigências metodológicas para uma maior compreensão de todo escopo teórico de Esquisse obriga-nos a apresentar o contanto, mesmo que mínimo de Sartre, com a ontologia de Heidegger ${ }^{23}$, pois o psicólogo, caso queira avançar em suas investigações, deverá partir do homem enquanto totalidade sintética e da realidade-humana enquanto esta é inseparável da noção de mundo: "o homem é um ser do mesmo tipo que o mundo, é mesmo possível, como acredita Heidegger, que as noções de mundo e de 'realidade-humana' (Dasein) sejam inseparáveis" (SARTRE, 1995, p. 13).

Seu Diário de uma Guerra Estranha, sobretudo o diário $\mathrm{XI}$, deixam entrever as dificuldades sartreanas ante o vocabulário de Heidegger: frustrado pelo fato de que as obras de Husserl não lhe forneciam respostas suficientes às suas indagações pessoais, pois caminhava para um consequente idealismo, Sartre lê a tradução de Que é metafisica? feita por Corbin e, graças a ela, resolve incursionar, em vão, uma leitura de Ser e Tempo, leitura essa que não passará das cinquenta páginas. Dirá ele:

Certamente, se Corbin não tivesse publicado sua tradução de Was ist Metaphysik?, eu não a teria lido. E, se eu não a tivesse lido, não teria me aventurado, na última Páscoa, na leitura de Sein und Zeit. (...) Mas, quando comecei a ler Heidegger, no mês de abril, eu já estava saturado de Husserl. Meu erro fora acreditar que se pode compreender sucessivamente dois filósofos dessa importância como aprendemos, um depois do outro, os comércios exteriores de dois países europeus. Husserl me envolvera, eu via tudo através das perspectivas da sua filosofia que, aliás, me era mais acessível por sua aparência cartesiana. Eu era 'husserliano' e assim ficaria por muito tempo. Ao mesmo tempo, o esforço que despendi para compreender, ou seja, para desfazer meus preconceitos pessoais e captar as ideias de Husserl, a partir de seus próprios princípios e não dos meus, me esgotara filosoficamente para todo aquele ano. Comecei Heidegger, e, ao fim de cinquenta páginas, a dificuldade do vocabulário me repeliu (SARTRE, 2005, p. 416 - 417).

Ainda de acordo com Sartre, a filosofia de Heidegger parecia bárbara e infantil depois da "genial síntese universitária de Husserl" (SARTRE, 2005, p. 418). O enredo final das

${ }_{23}$ Este "contato mínimo" diz respeito, como veremos, ao início da trajetória filosófica de Sartre. Na época da redação de Esquisse, o filósofo francês não havia ainda completado sua leitura da obra heideggeriana intitulada Ser e Tempo (1927). 
aventuras sartreanas na filosofia de Heidegger, sabemos, culminará na aparição de sua magnum opus L'être et le néant (1943). Por hora, gostaríamos apenas de indicar o teor de seu contanto com o autor de Que é a metafísica?. Se o filósofo-soldado, de um lado, mobiliza alguns conceitos oriundos do pensamento heideggeriano para a elaboração teórica de Esquisse, de outro, sua leitura frustrada de Ser e Tempo indica que lidamos ainda com um Sartre ainda muito ligado ao pensamento de Husserl, mesmo que essa ligação esteja amparada por uma constante tensão crítica do discípulo ao mestre.

De todo modo é interessante frisar, como o faz Dominique Janicaud em seu Heidegger en France (2006, p. 64), que a leitura sartreana de Heidegger irá enquadrar o homem como núcleo fundamental dessa filosofia. Expliquemo-nos. Sartre, ao filiar-se à tradução de Corbin do Dasein como "realidade-humana", acaba seguindo pela mesma esteira que inflexiona a esse conceito certo humanismo que não lhe diz respeito algum: a transcendência enquanto liberdade consciente, privilégio do homem; o Dasein, imantado de humanidade, mantém estrita ligação com o mundo. Além do comentário de Janicaud, Tomès, em sua apresentação-prefácio à edição francesa dos anos 2010 de Esquisse, precisará o seguinte:

Pode-se certamente ver em Ser e Tempo a origem da ideia segunda a qual o fato de existir recai sobre o homem como um modo de ser particular que supõe que ele não receba seu ser de fora, mas que ele o assume e é responsável por ele. E é isso que Heidegger, em sua Lettre sur l'humanisme, denunciara o contrassenso existencialista sobre sua definição do Dasein e relembrara que é necessário apreender o homem a partir do ser e não de uma pretensa essência de homem que daria sua especificidade: posição dita humanista que terá de uma certa maneira Sartre (...) (TOMÈS, 2010, p. 34).

Ora, dessa tradução humanista do termo heideggeriano podemos assinalar, nos quadros de Esquisse, que o evento psíquico deverá ser interrogado a partir de sua significação, que ele somente poderá significar algo na medida em que for fenômeno assumido por essa realidade-humana cujo mundo é-lhe inseparável. O significado será o todo da consciência, exprimirá o conjunto da realidade-humana definida como totalidade sintética. Grosso modo, 
a partir da "realidade-humana" vê-se um possível deslocamento conceitual do psíquico e, sobretudo, um marca existencial nas análises fenomenológicas ${ }^{24}$ da emoção. Se assim é, debrucemo-nos na introdução da presente obra a fim de asseverar esta nova posição das aventuras de Sartre na fenomenologia.

$\mathrm{Na}$ introdução da obra em comento, Sartre pretende operar uma crítica metodológica à psicologia de sua época, por conseguinte, uma crítica que se atém exclusivamente à objetivação do fato psíquico e ao estatuto da descrição realizado pelos psicólogos. Segundo o Autor, o psicólogo parte exclusivamente de fatos que não se organizam por si mesmos em uma totalidade sintética que "forneceria por si mesma sua significação" (SARTRE, 1995, p. 8), ou seja, ele parte de um dado empírico já constituído e que se repete com certa frequência: o psicólogo toma a noção empírica de homem sem tê-la, todavia, definido e limitado a priori. Em suma, ele ignora se o conceito de homem não é arbitrário, logo: "A psicologia espera utilizar o conceito de homem somente como um conceito a posteriori, construído pelo termo da operação experimental" (TOMÈS, 2010, p. 19). Entrementes, no caso particular da emoção, por falta de um conceito rigoroso de homem que teria permitido elucidá-la a partir da totalidade humana, o empirismo conduz o psicólogo a apreender a emoção como um fenômeno psíquico sem ligação essencial com outros fenômenos. Diante deste "descuido" psicológico, começamos a entrever o que distingue a elaboração psicológica da emoção - que não coloca em revelo a realidade-humana - da elaboração psicofenomenológica: "(...) uma vez a emoção isolada do resto da realidade-humana, o psicólogo explica-a, então, de acordo com a sua démarche analítica, privilegiando certos aspectos do fenômeno que ele novamente isolou" (CABESTAN, 2004, p. 39).

A consequência direta deste descuido conceitual é a de que há, para a psicologia, uma multiplicidade de fatos justapos-

$24 \quad$ Para Francis Jeason em Le problème moral et la pensée de Sartre (1965, p. 51), esta perspectiva "mais heideggeriana" de Esquisse assinala uma passagem da tendência essencialista que toma como crucial a constituição das significações à uma tendência existencial da fenomenologia que deverá analisar a realidade-humana do ponto de vista existencial. 
tos e não ordenados. Enfim, o métier psicológico diz respeito a essa característica indutiva que ira fornecer-nos apenas somas heteróclitas de fatos dispersos; o psicólogo aparece aqui como um mero colecionador de fatos isolados que espera o acidente ao essencial, o contingente ao necessário. Nesta senda, esperar o fato é, por definição, esperar o isolado, é preferir, por positivismo, o acidente ao essencial, o contingente ao necessário, a desordem à ordem; é transferir ao futuro, por princípio, o essencial: "é para mais tarde, quando tivermos reunido um grande número de fatos" (SARTRE, 1995, p. 12). A fatura desta crítica é incisiva: a ciência chamada psicologia não visa conhecer a totalidade sintética mundo e homem, antes, visa tão somente às possibilidades de certos fenômenos gerais. Outro fator preponderante para a confusão da definição de emoção é que o psicólogo não se pergunta, como o faz Husserl, acerca das possibilidades de uma intuição de essências, ele não se orienta em uma investigação eidética. Na sequência, evocando Heidegger com a intenção de fortificar sua crítica, Sartre afirma, como observamos, que este concebe o mundo e a realidade -humana como totalidades sintéticas inseparáveis. Diante disto, o psicólogo jamais apresentaria algum resultado satisfatório no estudo da emoção por não partir de uma definição de homem em estrita relação com o mundo. A coloração desta crítica metodológica poderia ser resumida da seguinte maneira:

A primeira crítica que Sartre endereça à psicologia positiva é sua ausência de sistematicidade. A psicologia positiva pretende se limitar à experiência na qual ela entende em sentido muito restritivo: esta experiência se limita a ser a experiência dos fatos. O psicólogo cientista não se pergunta se existe, como afirma Husserl, uma intuição de essências: ele pretende partir somente dos fatos, que ele define como qualquer coisa que se deve "encontrar no curso de uma investigação" e que "se apresenta sempre como um enriquecimento inesperado e uma novidade por ligação aos fatos anteriores". Sumariamente, seu estudo deve ser totalmente empírico e a posteriore (TOMÈS, 2012, p. 224).

\section{Ou ainda:}

A segunda crítica que ele endereça à psicologia de sua época é de passar sob silêncio as condutas mais gerais de possibilidade dos fenômenos psicológicos. Isso é evidentemente uma consequência do 
desejo de positividade: sendo dado que se trata de partir dos fatos, não estaria em questão partir das estruturas mais gerais (como o ser-no-mundo que fala Heidegger) ou de uma antropologia filosófica (TOMÉS, 2012, p. 225).

Ciência empírica e indutiva, a psicologia na época de Sartre apenas objetiva o psíquico, torna-o mero fruto do acaso, coleção vã de fatos distintos que, somados, jamais chegariam a nenhum resultado concreto. No estudo particular das emoções, a descrição empírica da psicologia nada assevera sobre elas, antes, apresenta-as como uma simples desordem sem lei, como um mero acidente de percurso. Sem indagar sobre as condições de possibilidade de uma emoção, o psicólogo abjura uma compreensão mais vasta da realidade-humana como possível efetuadora das emoções. Ademais, esta compreensão parece até mesmo risível no nível desta ciência impregnada de positividade e empiria:

Quanto ao estudo das condições de possibilidade de uma emoção, isto é, perguntar se a estrutura mesma da realidade-humana torna as emoções possíveis e como as torna possíveis, isso pareceria ao psicólogo uma inutilidade e uma absurdidade: de que serve investigar se a emoção é possível, já que precisamente ela é? É à experiência igualmente que o psicólogo se dirigirá para estabelecer os limites dos fenômenos emotivos e sua definição (SARTRE, 1995, p. 14 - 15).

A investigação psicológica não busca as leis da emoção em totalidades sintéticas e essenciais da realidade humana, "mas, ao contrário, nos processos da própria emoção" (SARTRE, 1995, p. 16), emoção concebida apenas como fato entre tantos outros fatos que nada significam. Manifestando um desejo profundo de positividade, a letra do discurso psicológico está centrada na experiência sensível ou na experiência reflexiva que pressupõe certa representação normativa ou certa tese sobre o que deva ser a experiência. Disso, Sartre afirma que o empirismo da psicologia permanece insuficiente para a reconstituição da essência do homem e, por conseguinte, para a explanação, em filigrana, do fenômeno emotivo. Doravante, contra as insuficiências desta ciência, Sartre convocará a fenomenologia de Husserl pela qual seremos capazes de distinguir a incomensurabilidade existente entre as essências e os fatos; 
acerca desta incomensurabilidade entre fato e essência, lemos: "Se procuro os fatos psíquicos que estão na base da atitude aritmética do homem que conta e calcula, jamais chegarei a reconstituir as essências aritméticas de unidade, número e de operações" (SARTRE, 1995, p. 17).

Em fenomenologia, cuja base de seu método é o da intuição eidética, se falamos de experiência, ao menos, referimo-nos à experiência das essências e dos valores; doravante, a noção conceitual de eidos opera uma verdadeira diferença teórica entre esta e a psicologia porque é preciso considerar que "apenas as essências permitem classificar e inspecionar os fatos" (SARTRE, 1995, p. 17). Sobremaneira, ao principiar suas investigações a partir dos fatos psíquicos isolados de sua essência, o psicólogo não vislumbrará jamais o homem no mundo, ou seja, não alcançará as emoções enquanto reações humanas contra o mundo (e, assim, providas de significação). Nesta ótica, é preciso consolidar uma dada investigação que tome como crucial para seu desenvolvimento a elucidação destas duas totalidades sintéticas: homem \& mundo.

Até este ponto, a démarche da crítica de Sartre à psicologia ateve-se exclusivamente a noção capital de essência. Se no opúsculo sobre o ego transcendente a censura à psicologia havia sido operada graças ao desconhecimento que esta possuía acerca da consciência espontânea irrefletida, aqui, trata-se de elucidar a origem do homem em situação, do psíquico e do mundo. Daí que seja intrínseco partir das análises da essência da consciência constitutiva, pois o objetivo do estudo da emoção é mostrá-laenquanto significação das essências das totalidades sintéticas: todo fato humano é, por essência, significativo. A psicologia fenomenológica buscará compreender as emoções a partir das relações da consciência com o mundo e, neste registro, ela deverá operar uma investigação eidética acerca dessas totalidades sintéticas. Explanar as totalidades sintéticas significa, por seu turno, dirigir-se às coisas mesmas, apreendê-las em carne e osso, isto é, enquanto eidos. Significa, finalmente, trabalhar com os ganhos teóricos da filosofia husserliana conquistados através da ideia de intencionalidade: "Husserl sabe 
tirar proveito dessa proximidade absoluta da consciência em relação a si mesma e da qual o psicólogo não quis se servir" (SARTRE, 1995, p. 19). Contudo, ainda que Husserl defenda que a psicologia deva ter como ponto de partida as análises fenomenológicas da essência do psíquico, ele não afirma que ela (a psicologia) não seja pertinente e que, por isso mesmo, deva excluir sua própria visão do fato psíquico ${ }^{25}$. Ainda mais radical que a crítica husserliana, Sartre pretende contestar a legitimidade desta psicologia que trata o fenômeno psíquico como um fato entre outros fatos coletados graças à observação empírica e a posteriore. Se o que sublinhamos é correto, as preocupações sartreanas estão intimamente ligadas a um projeto radical que visa instituir a démarche fenomenológica como método para corrigir os quiproquós da psicologia; logo:

\begin{abstract}
É bem a um outro tipo de psicologia que Sartre aspira no Esboço de uma teoria das emoções: uma psicologia que reintegraria a dimensão do homem e a dimensão do sentido, e que seria irredutível à psicologia empírica e até mesmo à psicologia fenomenológica, no sentido onde Husserl emprega essa expressão. (...) A crítica dos fundamentos da psicologia está articulada ao projeto de construir uma psicologia mais completa, que apreenderia o fenômeno psíquico em sua especificidade sem confundi-lo nem com o fato da psicologia empírica, nem com a essência pura da fenomenologia transcendental (TOMÈS, 2012, p. 227-228, grifo nosso).
\end{abstract}

Nem fato e nem essência pura, o psíquico será um fenômeno constituído a partir da experiência da consciência com o mundo: daí porque a psicologia fenomenológica sartreana, num distanciamento para com Husserl, não tratará do problema entre a articulação do Eu transcendental e do Eu mundano. Problema que, como havia sido colocado desde La transcendance de l'Ego, já fora ultrapassado na exata medida em que o transcendental e o empírico formavam ali um díptico que excluía qualquer necessidade de uma esfera normativa (no caso, o Eu transcendental que regularia, fora do fluxo concreto das vivências, a realidade). Além do mais, a nova teoria psíquica esboçada pelo filósofo francês traz em seu bojo os anseios de um retorno ao concreto,

${ }_{25} \quad$ A referência sobre este ponto pode ser encontrada na obra husserliana Ideias para uma fenomenologia pura e para uma filosofia fenomenológica (1913), mais explicitamente na introdução da obra e no § 79. 
a superação de uma vida interior do espírito tal como postulada pela geração anterior a de Sartre (os filósofos franceses dos anos de 1900 ou, para falar como Worms (2009, p. 194-199), os pensadores do momento do espírito).

Ora, se o que está em jogo aqui é uma (re)formulação completa da emoção, tudo indica que somos obrigados, além de passar pelas essências da estrutura da consciência, explicitar a emoção como fenômeno consciente que exprime o todo da realidade-humana definida, por seu turno, como totalidade sintética. Acerca desta segunda condição para bem conduzir as investigações emotivas, Esquisse reenquadra positivamente a consciência transcendental outrora esquadrinhada no opúsculo sobre o Ego transcendente, o que significa que aqui ela passa a dizer respeito a mim, e isso só é possível à medida que Sartre, leitor (ainda prematuro) de Heidegger, mobiliza o Dasein como realidade-humana $^{26}$. A assunção de si que caracteriza a realidade-humana implica, necessariamente, uma compreensão desta realidade-humana por si mesma e as investigações fenomenológicas, por sua vez, devem ater-se a este dado fundamental, pois o existente, caracterizado pela figura da humanidade, sempre assume seu ser, ele é responsável por suas escolhas no mundo. Amparado por Heidegger (melhor, por uma leitura humanista da filosofia heideggeriana), Sartre poderá afirmar que a especificidade do homem consiste em "uma certa forma de compreensão de si que diz respeito ao ser do homem ou mais precisamente à matéria na qual o homem se relaciona com seu ser" (TOMÈS, 2010, p. 29). E acerca desta especificidade do homem, lê-se:

Ora, não é indiferente que esta realidade-humana seja minha porque, precisamente para a realidade-humana, existir é sempre assumir seu ser, isto é, ser responsável por ele em vez de recebê-lo de fora como faz uma pedra. E como "a realidade-humana" é por essência sua própria possibilidade, este existente pode "escolher-se" ele próprio em seu ser, pode ganhar-se, pode perder-se (SARTRE, 1995, p. 20).

Doravante, compreender o homem é compreendê-lo a partir de si mesmo, o que significa dizer que só nos fazemos ho-

$26 \quad$ Não nos esqueçamos que a leitura sartreana de Heidegger, como bem assevera Dominique Janicaud, é eminentemente humanista. 
mens na exata medida em que nos compreendemos como tal. Ao contrário do psicólogo que parte apenas de fatos heteróclitos, o fenomenólogo deverá perquirir, em primeiríssimo lugar, a totalidade sintética que é o homem estabelecendo e fixando seu ser com a finalidade de, finalmente, desvendar a essência da conduta operada pela emoção. Em Heidegger, existir é para a realidade-humana assumir seu próprio ser através de um modo existencial de compreensão e para Husserl, a existência é sempre o "aparecer a si mesmo" da consciência. O primeiro dirá que podemos reencontrar o todo da realidade-humana graças ao estudo da emoção que "é a realidade-humana que se assume ela própria e se “dirige-emocionada”' (SARTRE, 1995, p. 23); já o segundo, realizará uma descrição fenomenológica da emoção desvelando as estruturas fundamentais da consciência (já que a emoção é precisamente um tipo de consciência que segue leis eidéticas particulares). A polaridade Husserl/Heidegger instaura a tônica metodológica da investigação que se operará no registro das emoções: a emoção será interrogada a partir da consciência e do homem. Deste modo, os resultados da psicologia fenomenológico-eidética, totalmente em oposição aos fatos heteróclitos, dispersos e desorganizados da psicologia, será capaz de obter respostas sobre este ser cuja característica essencial é justamente a de ser capaz de emocionar-se. Deste modo, a pergunta eidética a ser feita é a seguinte: "o que deve ser uma consciência para que a emoção seja possível, talvez até mesmo para que ela seja necessária?" (SARTRE, 1995, p. 24, grifo nosso). Não obstante, a emoção, muitas vezes considerada mera desordem subjetiva sem nenhum tipo de lei, ao passar pelo exame de uma fenomenologia que trabalha no duplo registro da realidade-humana e da consciência, revelar-se-á uma reação da consciência, do homem em situação diante do mundo, pois a emoção é menos um fato psicológico do que uma resposta a uma situação, a emoção é a "reposta (ativa ou passiva) a uma situação" (MOUILLE, 2000, p. 70). A diferença entre a psicologia e a fenomenologia está, portanto, no modo como cada uma enquadra teoricamente o psíquico: para a primeira, o psíquico será desordem subjetiva observável empiricamente, já para a segunda, ele será fenômeno de uma consciência no mundo, 
ele integrará a realidade-humana, o que significa(re)defini-lo como psíquico fenomênico, (re)definição que traz em seu bojo o conceito de significado.

Se em La transcendance de l'Egoo psíquico era um objeto transcendente que não se dava no fluxo concreto dos vividos, em Esquisse, ele passará a integrar a consciência, será um fenômeno da consciência diante do mundo, uma nova variação eidética desta explanando a realidade-humana que se assume a si mesma: "é enquanto fenômeno que podemos alcançar a essência do psíquico e por aí fornecer bases sólidas para 'as generalizações do psicólogo (...)” (MOUTINHO, 1995, p. 101). Reenquadrar o psíquico como fenômeno significa, além disso, considerá-lo significante e como assumido pela realidade-humana: "para a fenomenologia, todo fato humano é, por essência, significativo. Se você remove dela a significação, você remove sua natureza de fato humano" (SARTRE, 1995, p. 24). Esta significação deve ser compreendida como aquilo que indica outra coisa, pois, significar é indicar esta outra coisa de tal modo que, "desenvolvendo a significação, encontrar-se-á precisamente o significado" (SARTRE, 1995, p. 25). Se o modus operandi da psicologia não se dá em regime de essência, também seria impossível a ela observar que a emoção significa algo. Para o psicólogo, ao contrário deste "significar algo", o fenômeno emotivo é, desde sua origem, não-significante, não-psíquico, em suma, não passa senão de um mero fato. Nas tramas de Esquisse, e ao contrário da glosa psicológica, nós deveremos considerar a emoção como significante, daí a tarefa da psicologia fenomenológica, qual seja: explicitar e elucidar a significação das condutas da consciência emocionada: "ao invés de fato puro, o evento psíquico deve pois ser interrogado na medida em que é significação" e "ele só significa algo na medida em que é subjetivo, não um evento puro e simples" (MOUTINHO, 1995, p. 102).

A emoção deverá ser considerada sob o prisma fenomenológico-existencial, ela portará uma essência, terá estruturas organizadas e particulares: "a emoção é uma forma organizada da existência humana" (SARTRE, 1995, p. 26). Finalmente, 
podemos assinalar com mais rigor a fatura do díptico Husserl/ Heidegger: devemos falar da emoção tendo em vista tanto as leis eidéticas da consciência como a realidade-humana que assume seu próprio ser através de um modo existencial de compreensão. Nesta toada, a psicologia fenomenológica, a partir do expediente conjugado da realidade-humana e da consciência, irá fornecer-nos as estruturas eidéticas da consciência na qual a emoção, por seu turno, representa o todo da realidade-humana que se assume ela mesma emocionada: a afetividade humana só será possível se houver uma predisposição existencial do homem em ser afetado.

Devidamente instalada no terreno fenomenológico/eidético das significações, a psicologia, posta neste bom caminho, abandonaria o método de introspecção indutiva e o método da observação empírica externa, ater-se-ia somente a fixar a essência dos fenômenos constitutivos da realidade-humana afirmando, portanto, a emoção como reação do homem diante do mundo: "ela se daria, então, por uma ciência eidética" (SARTRE, 1995, p. 29). Doravante, caso queiramos saber se a emoção é verdadeiramente um fenômeno significante, é preciso, no típico gesto fenomenológico, "ir às coisas mesmas", ou seja, partir da significação como estrutura fundante da consciência emotiva. Deslocando-nos da coleção de fatos dispersos à significação, Sartre:

Em seu Esboço, começa por convidar-nos, à luz de uma crítica das perspectivas clássicas, a revelar a consciência enquanto consciência. A psicologia seria apenas um simples estudo de fatos, o psicólogo não deve esperar dos eventos interiores que eles se organizem por si mesmo ou segundo as normas preestabelecidas de uma consciência transcendental, impessoal, estranha à consciência concreta. Cada um desses eventos é um advento, uma aparição por onde a consciência se manifesta em sua situação no mundo e em sua própria atitude face a face desta situação: é, por conseguinte, um 'fenômeno', que, não podendo se remeter a nenhum outro ser, a nenhum outro 'noema' - cuja consideração seria psicologicamente vã -, remete-se ao menos a seu autor e significa a totalidade da consciência lançada em uma atitude particular (JEASON, 1965, p. 41-42).

A partir da consciência em situação no mundo, constataremos que o fenômeno emotivo não é uma desordem, um 
fato contingente observável apenas do ponto de vista empírico, ponto de vista de uma psicologia positivista que, desconhecendo a especificidade do fenômeno psíquico, desconhece as leis eidéticas da consciência. Ora, se se almeja elucidar a gramática da emoção, é imperativo que as disciplinas psicológicas assumam, por meio dos dispositivos fenomenológicos, o conceito capital de significação: "Nós procuraremos nos colocar sobre o terreno da significação e tratar a emoção como fenômeno" (SARTRE, 1995, p. 30).

\section{A psicologia fenomenológica como detalhamento das aventuras da consciência no mundo}

Escrutinemos melhor os nossos passos antes de adentrarmos efetivamente na elaboração da psicologia fenomenológica proposta pela obra em tela. Primeiramente, é preciso convir que Esquisse irá instituir uma diferença teórica em relação ao já mencionado ensaio sobre o Ego transcendente. No artigo dos anos 1937, o psíquico aparece como objeto transcendente, região cujo métier era contrário ao campo transcendental pré-pessoal/impessoal, sem sujeito; o psíquico fomentava, lá, uma esfera não-fenomenológica. A fatura destes dois 'domínios' marcava, por assim dizer, a separação entre a consciência translúcida de um lado, e o psíquico viscoso e obscuro do outro, separação que fazia advir dois tipos de reflexão, quais sejam: aquela de tipo pura e adequada que respeitava a apoditicidade da apreensão instantânea da consciência sobre o objeto pelo fato de que sinalizava a diplopia singular através da qual o momento constitutivo e o momento mundano instauravam, ao mesmo tempo, a realidade dos objetos transcendentes. Sendo assim, a reflexão pura atinha-se exclusivamente à imanência intencional do campo transcendental, respeitando o grau zero de aparição do X qualquer. Já a reflexão impura, por sua vez, era compreendida como condição de possibilidade do aparecimento do Ego psíquico e, junto dele, a inadequação com a qual apreendíamos o objeto: por exemplo, a repulsa passava ao ódio e o ódio era dado como íntimo ao afirmar sua permanência no futuro; n'outras palavras, a reflexão impura transbordava a 
instantaneidade da presença do X qualquer à consciência. Produtora de falsas interioridades, nesta esfera psíquica impura os estados, ações e facultativamente as qualidades eram apreendidos como produzindo a consciência e emanando do Ego. En résumé, a reflexão pura estava do lado do real instituído fenomenologicamente e a reflexão impura, domínio do equívoco e do erro, estava do lado do mágico (irracional). Esta distinção entre ambas as reflexões, nas tramas do ensaio, era resultante da própria definição da consciência como consciência transcendental impessoal e atemporal (instantânea, ex nihilo). Em Esquisse, par contre, o psíquicoserá fenomênico, aparecerá no registro da essência do homem, isso porque a realidade-humana, termo heideggeriano passado pelas lentes sartreanas, asseverará a facticidade emotiva da consciência. Como dissemos alguns parágrafos mais acima, a emoção e por conseguinte o psíquico passam a constituir uma nova variação eidética desta consciência que, até os anos 1937, era tão somente consciência de (si) e consciência dos objetos instantaneamente presentes a ela. Nos termos da obra dos anos 1939, a investigação fenomenológica-existencial da consciência deverá estabelecer a emoção como fenômeno significante de consciência, fenômeno que significa algo para além de si mesmo. Sendo assim, a emoção será um modo da intencionalidade, uma consciência do mundo, mais, ela será uma consciência aberta ao mundo cujos meios são deterministas.

As devidas rememorações tecidas, marquemos com mais rigidez nosso percurso até o presente momento: o ensaio que inaugura a morte do sujeito - Essai sur la transcendance de l'Ego -, condensa a separação entre fenomenologia (ciência rigorosa dos fatos de consciência) e o psíquico (objeto de estudos da ciência chamada psicologia). Acrescido do pequeno artigo-panfleto de feições enragée - Une idée fondamentale de la phénoménologie de Husserl: intentionnalité -, o filósofo francês forja as diretrizes teóricas da consciência como intencionalidade, ou seja, como pura atividade de transcendência para fora de si mesma. Essai, somado ao artigo-panfleto, inaugura o modo como Sartre se apropria da fenomenologia husserliana e, ao mesmo tempo, sua diferença em relação às concepções 
psicológicas da época. Na sequência da produção intelectual e filosófica de Sartre, Esquisse sinaliza, agora, não só a passagem da psicologia à fenomenologia, mas, sobretudo, a passagem da fenomenologia de Essai à psicologia fenomenológica. Desta passagem de um polo a outro, não poderíamos, aliás, de deixar de notar que o papel do corpo também sofrerá uma mudança teórica significativa. Se no referido Essai o corpo estava intimamente ligado à teoria do Ego psíquico, ou seja, sua aparição era o resultado de uma psicologia não fenomenológica, como deveremos reordená-lo na psicologia tornada fenomenológica, qual será seu papel nas tramas da obra dos anos de 1939? Tendo em vista tais questionamentos, debrucemo-nos no texto e façamos emergir a crítica sartreana dos métodos psicológicos.

Se a crítica havia revelado o descuido da psicologia para com a essência da emoção, precisamente o fato de que ela significa algo, é preciso convir neste momento que o saber psicológico parte essencialmente da consciência reflexiva, logo, ele toma a emoção enquanto produto desta, como um mero fato de consciência. Incontáveis vezes fomos alertados de que a origem da consciência se reporta sempre ao nível irrefletido,o que aqui não seria diferente: a consciência emocional é primeiramente consciência irrefletida, consciência não-posicional/não-tética de si, em suma, ela é consciência do mundo. Este último princípio, aparentemente simples, descortina a ligação elementar entre a consciência e o mundo, dois planos complementares que são dados de uma só vez, duas instâncias interdependentes que forjam a realidade; daí que a emoção surja como fenômeno de uma consciência no mundo (consciência enquanto ser-no-mundo):

É evidente, de fato, que o homem que tem medo, tem medo de alguma coisa. Mesmo que se trate de uma dessas angústias indefinidas que provamos na noite, em um caminho sinistro e deserto, etc., é ainda de certos aspectos da noite, do mundo, que temos medo. (...) a emoção retorna a todo instante ao objeto e dele se alimenta. (...) Em uma palavra, o sujeito emocionado e o objeto emocionante estão unidos em uma síntese indissolúvel. A emoção é uma certa maneira de apreender o mundo(SARTRE, 1995, p. 70-71).

Este pequeno excerto esclarece a démarche da consciência emotiva. A emoção é sempre um fenômeno que mantém es- 
trita relação com o objeto. A fuga, exemplo usado pelo filósofo, revela esta íntima relação entre ambas: ela (a fuga) é sempre fuga diante de um certo objeto. Esta relação da emoção com o mundo também poderia ser aplicada no exemplo da experiência da Gestalt: pede-se a um sujeito que tente alcançar um objeto qualquer sem que ele ultrapasse os limites do círculo no qual ele está e que fora propositalmente desenhado para que a ação não seja possível. Sem conseguir realizar satisfatoriamente o que lhe fora exigido, o sujeito se irrita e esta irritação "é ainda uma maneira de como o mundo aparece a ele" (SARTRE, 1995, p. 72). É da mais alta importância que sublinhemos esta relação da emoção com o mundo, pois, no desenvolvimento de nossas investigações, veremos que a emoção é um fenômeno consciente de transformação do mundo ou, como dissemos, uma consciência do mundo.

Retornando à experiência da Gestalt balizada pelo pensamento sartreano, a ação que fracassa e a cólera que irrompe deste fato marcam o movimento da consciência: "pode haver passagem contínua da consciência irrefletida 'mundo-agido' (ação) à consciência irrefletida 'mundo-odioso' (cólera). A segunda é uma transformação da outra" (SARTRE, 1995, p. 72). O autor alerta-nos, todavia, que a ação poderia ser pensada como uma passagem constante do irrefletido ao refletido, mas, como veremos, podemos admitir que uma ação possa ser executada sem que o sujeito deixe o plano irrefletido da consciência em prol do plano reflexivo. A explanação em filigrana da conduta irrefletida é essencial para que levemos a cabo a objeção que talvez fosse colocada pelos defensores da psicanálise, qual seja: "se a consciência organiza a emoção como um certo tipo de resposta adaptada a uma situação exterior, como explicar então que ela não tenha consciência dessa adaptação?” (SARTRE, 1995, p. 67).

Esta crença de que a ação é uma passagem constate do irrefletido ao reflexivo parece relevar-se do seguinte modo: nós perceberíamos o problema posto (irreflexão - consciência do mundo), em seguida nós perceberíamos a nós mesmos como portadores desse dado problema (reflexão). Uma vez realiza- 
da esta suposta reflexão, buscaríamos uma ação para tentar saná-lo (reflexão), e logo em seguida, executaríamos a ação (irrefletida) tendo em vista o objeto. Entretanto, é preciso convir que a consciência irrefletida é um absoluto que opera em constante regime de autarquia. Por isso, mesmo que haja ação, o indivíduo não precisa necessariamente sair do plano irrefletido para realizá-la. A fim de tornar presente esta concepção da totalidade do irrefletido, acompanhemos de perto a passagem longa, porém preciosa, dada por Sartre: no momento da escrita, não temos consciência de escrever. A explicação pelo hábito também não seria válida porque posso estar habituado com a escrita, mas não haveria hábito ao escrever tais palavras em tal ordem precisa. Antes de ser inconsciente, o ato de escrever é irrefletido, uma estrutura atual de minha consciência não-posicional. O referido exemplo ater-se-á a demonstração da ação como constituidora da camada de objetos em um mundo provável, o sujeito não tem necessidade alguma de estar consciente de si como agente para agir; lê-se:

Escrever é tomar uma consciência ativa das palavras enquanto elas surgem de minha pena. Não das palavras enquanto são escritas por mim: apreendo intuitivamente as palavras enquanto elas possuem essa qualidade de estrutura de surgirem ex nihilo e, não obstante, de não serem criadoras por si mesmas. No momento mesmo no qual eu traço uma das palavras, não presto atenção isoladamente em cada uma das pernas de letras que minha mão forma: eu estou em um estado especial de espera, a espera criadora, eu espero que a palavra - que sei de antemão - sirva-se da mão que escreve e das pernas de letras que ela traça para se realizar. E, com certeza não estou consciente das palavras da mesma forma que quando leio o que uma pessoa escreve, olhando por cima de seu ombro. Mas isso não quer dizer que eu esteja consciente de mim como escrevente. As diferenças essenciais são essas: primeiramente, minha apreensão intuitiva do que meu vizinho escreve é do tipo "evidência provável". Mas, no momento em que, lendo "indep...", percebo intuitivamente "independente", a palavra "independente" se dá como uma realidade provável (à maneira da mesa ou da cadeira). Ao contrário, minha percepção intuitiva das palavras que escrevo me apresenta essas palavras como certas. Trata-se de uma certeza um pouco particular: não é certo que a palavra "certeza", que estou em via de escrever, vá aparecer (posso ser interrompido, mudar de ideia, etc.), mas é certo que, se aparecer, aparecerá desta maneira. (...) a exigência das palavras que traço é diretamente presente, sentida e pesada (SARTRE, 1995, p. 73-75). 
Este fragmento contém, além da resposta contra a possível objeção levantada pelos defensores da psicanálise, uma oposição ao inconsciente: a consciência irrefletida é consciente de si mesma não-téticamente. Somente ao transcender-se e perceber-se no mundo como uma qualidade, a consciência passa a ser téticamente consciente de si mesma. Na ação da consciência de primeiro grau, os objetos do mundo aparecem como devendo ser realizados por certos caminhos, "os meios aparecem como potencialidades que reclama a existência" (SARTRE, 1995, p. 76), vide, por conseguinte, a ação de escrever. O mundo emerge aqui como uma totalidade sintética na qual as ações encontrariam meios precisos para chegar a seu objetivo. Este mundo de atos, necessidades e desejos, aparece como que sulcado por caminhos precisos, estreitos e rigorosos que conduzem a este ou àquele dado objetivo determinado. Enfim, é preciso sublinhar a ordenação dos meios no qual a ação deve organizar-se: existem diversos meios para que uma ação se realize, mas estes diversos meios são os únicos meios possíveis, daí a observação de que o mundo é difícil. Esta noção de dificuldade, antes de partir da consciência, é uma noção que irrompe e marca uma qualidade do próprio mundo. É necessário ater-se à relação do mundo com a consciência, ou, se quisermos, a esta consciência mundana porque ela marca a definição de emoção.

No entanto, antes de avançarmos na abertura da consciência ao mundo, faz-se necessário que fiquemos atentos ao fato de que Sartre, mobilizando o exemplo da escrita como ação de uma consciência irrefletida, nota que o mundo contribui ao esquecimento de si dessa consciência engajada na conduta de primeiro grau: "sob a luz de um fim qualquer, o mundo aparece como um complexo de meios que convidam por eles mesmos a empregá-los, a servir-se deles (...). Há somente que se deixar guiar pelas potencialidades inscritas nas coisas" (COOREBYTER, 2012, p. 276). Se a conduta irrefletida se deixa guiar por essas potencialidades inscritas nas coisas sob fundo de uma intuição pragmática do determinismo do mundo, é preciso admitir, todavia, que na conduta irrefletida o corpo é vivido como instrumento pelo qual as coisas se realizam: por exemplo, a mão do autor é um instrumento através do qual as palavras se 
realizam. Em outras palavras, a consciência irrefletida engajase no mundo prático que faz com que ela se deixa guiar através das potencialidades inseridas nas coisas. Na conduta emotiva, ao contrário, a consciência irrefletida, através de sua espontaneidade radical, mudará suas relações com o mundo, irá apreendê-lo como mundo mágico onde posso mudar minha relação com os objetos, resistir à suas potencialidades. Na conduta emotiva observaremos os embates da consciência espontânea contra o mundo determinista (e recheado de dificuldades).

Dissemos a pouco que a apreensão do meio como único caminho possível para alcançar o objetivo proposto definia a estrutura determinada do mundo. Esta apreensão do meio, podemos chamá-la de "intuição pragmática do determinismo do mundo". O mundo, com sua dificuldade, é o correlativo noemático de nossas atividades empreendidas ou simplesmente concebidas. Até então "ausente" de La transcendance de l'Ego, o mundo só se fazia aparecer através das circunstâncias especiais descritas por Heidegger em Ser e Tempo. Nas atuais conjecturas de Esquisse, ele (o mundo) irrompe como portador dos meios precisos à realização das ações do sujeito. Se havia uma relação fundante entre consciência e mundo nos quadros do Essai, ou seja, a consciência era essencial ao mundo na medida em que o mundo era essencial a esta (dada a necessidade do objeto para que a consciência aparecesse como consciência consciente do objeto) ${ }^{27}$, aqui, doravante, esta relação é mantida, porém, intensificada: o mundo, na exata emergência da realidade-humana, irá sublevar-se a esta potencialidade instauradora de meios ordenados e, por acréscimo, à aparição da consciência emotiva. Neste ritmo:

Neste momento podemos conceber o que é uma emoção. É uma transformação do mundo. Quando os caminhos traçados se tornam excessivamente difíceis ou quando não vemos caminhos, nós não podemos mais permanecer nesse mundo tão urgente e tão difícil. Todas as vias estão barradas, no entanto é necessário agir. Então tentamos mudar o mundo, isto é, vivê-lo como se as ligações das coisas com suas potencialidades não fossem regradas por processos deterministas, mas pela magia (SARTRE, 1993, p. 79).

\footnotetext{
$27 \quad$ Os termos dessa relação podem ser expressos ainda com a seguinte fórmula: a consciência só é consciência de si mesma na exata medida em que ela é consciência do objeto transcendente.
} 
Notemos que não se trata, para falar como o próprio Sartre, de um jogo. Na verdade, quando nos percebemos acuados diante dos processos deterministas do mundo, laçamo-nos com todas as forças nesta nova atitude que visa modificar a relação das potencialidades dos objetos com os meios determinados oriundos da totalidade sintética mundo. Frisemos, ainda, que esta modificação não é consciente enquanto tal, ela é "a apreensão de ligações novas e de exigências novas" (SARTRE, 1993, p. 79). A impossibilidade ou o engendramento de uma tensão insuportável faz com que a consciência apreenda o objeto de uma nova maneira, ela se transforma para poder então transformar o objeto em questão, logo, ela se transforma para transformar as potencialidades dos objetos em detrimento aos meios. Vê-se que a aparição da emoção enquanto atividade eidética da consciência só é possível graças a apreensão deste mundo traçado por caminhos, meios determinados. Sendo assim, o deslocamento teórico operado por Esquisse no que tange ao psíquico deve ser concebido através da irrupção do mundo no horizonte das intenções da consciência. Diante de tais dados, os mecanismos da emoção são desvelados: ela é um fenômeno de consciência que visa mudar uma intenção ou uma conduta e ela se entrega no plano irrefletido da consciência. A trama e a motivação da passagem parecer ser esta:

A impossibilidade de encontrar uma solução ao problema apreendido objetivamente como uma qualidade do mundo, serve de motivação à nova consciência irrefletida que apreende agora o mundo de outro modo e sob um aspecto novo que ordena uma nova conduta - através do qual este aspecto é captado - e que serve de hylé à nova intenção. Mas a conduta emotiva não está no mesmo plano que as outras condutas, ela não é efetiva. Ela não tem por finalidade agir realmente sobre o objeto enquanto tal através de meios particulares (SARTRE, 1995, p. 81).

A conduta emotiva buscará conferir ao objeto uma outra qualidade sem, no entanto, modificá-lo em sua estrutura real, ela conferirá a este $\mathrm{X}$ qualquer uma menor ou maior existência, ou uma menor ou maior presença. É importante sublinhar, ademais, que a emoção não é um fenômeno capaz de alterar verdadeiramente a estrutura real do objeto e sua relação com os meios determinados. Aquém disso, a emoção é uma 
transformação que a consciência realiza de si mesma e do objeto visado. Na verdade, a consciência emotiva mascara-separa mascarar o objeto visado e, neste ato, o corpo é convocado: "é o corpo que, dirigido pela consciência, muda suas relações com o mundo para que o mundo mude suas qualidades" (SARTRE, 1995, p. 82). A convergência do psíquico ao corpo é novamente tematizada nos quadros desta obra, muito embora se trate agora de abordar este psíquico do ponto de vista fenomênico e não transcendente. Sem partir de uma concepção fisiologista, biológica da emoção, o filósofo assinala qual deve ser nosso ponto de partida e também o de chegada: a consciência e seus mecanismos constitutivos e fundantes. Sobremaneira, o corpo irrompe nas tramas da obra em comento como o ser pelo qual as emoções se concretizam no mundo assim como, em Essai, o corpo era um enriquecimento sintético, factual do psíquico. Seria interessante destacar, no entanto, que o corpo de Essai é privado "da articulação íntima com a consciência, o corpo se reduz a um puro 'objeto do mundo"' (COOREBYTER, 2000, p. 543) na medida em que as análises sartreanas eram análises acerca do campo transcendental impessoal (consciência transcendental). Em Esquisse tudo indica que Sartre mantenha esta relação do corpo com a consciência, ainda que não se trate mais de analisar aquele campo transcendental impessoal, mas a variação eidética desta consciência enquanto consciência emotiva: "em uma palavra, na emoção, é o corpo que, dirigido pela consciência, muda suas ligações com o mundo para que o mundo mude suas qualidades" (SARTRE, 1995, p. 81-82). Neste sentido, somos forçados a admitir que caso queiramos restituir a experiência da emoção, deverá ser na consciência e não no corpo que deveremos começar esta empreitada fenomenológica. Isso porque, como viemos sublinhando, a emoção é primordialmente um fenômeno (significante) da consciência diante dos meios determinados do mundo. Mais ainda, a emoção é a realidade-humana se realizando sob a forma emotiva, ela expressa o todo da consciência, a consciência emocional. Almejando elucidar a essência finalista da emoção, Sartre propõe-nos um exemplo acerca do medo passivo; acompanhemo -lo de perto: 
Vejo vir em minha direção um animal feroz, minhas pernas fraquejam, meu coração bate mais lentamente, empalideço, caio e desmaio. Nada parece menos adaptado do que esta conduta que me deixa sem defesa ao perigo. E, no entanto, é uma conduta de evasão. O desmaio é aqui um refúgio. Mas não se pense que é um refúgio para mim, que busco me salvar, não ver mais o animal feroz. Eu não saí do plano irrefletido: mas, por não poder evitar o perigo pelas vias normais e pelos encadeamentos deterministas, eu o neguei. Eu quis aniquilá-lo. A urgência do perigo serviu de motivo para uma intenção aniquiladora que comandou uma conduta mágica (SARTRE, 1995, p. 83).

O fragmento acima esboça a conduta da finalidade emotiva diante das urgências de um mundo cujos encadeamentos deterministas não podemos ou não conseguimos seguir. A impossibilidade de suprimir um perigo iminente pelas vias deterministas do mundo faz com que sigamos uma conduta mágica. Em um exemplo anterior a este, Sartre evoca a mudança de atitude diante de um cacho de uva que não conseguimos alcançar. Se outrora este cacho aparecia como "devendo ser colhido", no fracasso da ação, na falta de realização da potencialidade, nós fazemos com que uma nova qualidade paire sobre ele: "de cacho de uva a ser colhido" para "cacho de uva muito verde"; o fracasso da ação muda (magicamente) a qualidade do objeto. Todavia, como não posso conferir quimicamente esta qualidade às uvas, "então capto o amargor da uva muito verde através de uma conduta de aversão" (SARTRE, 1995, p. 83). A tessitura fundamental da emoção está ancorada nesta finalidade que transforma magicamente os meios deterministas do mundo, transformação mágica que não age senão na estrutura fenomenal das coisas, isto é, em seu modo de aparecer.

No caso do medo passivo, a emoção aniquila o animal feroz que avança em minha direção através do desmaio, ela o suprime como objeto de consciência suprimindo a si própria: "são estes os limites de minha ação mágica sobre o mundo" (SARTRE, 1995, p. 84). A conduta fisiológica solicitada pela consciência emotiva opera uma verdadeira passagem da vigília ao sono, não há pura desordem nessa passagem de um estado ao outro, antes, há uma finalidade conduzida pela consciência irrefletida diante da impotência de qualquer ação. No caso do medo ativo, teorizado equivocadamente como uma conduta ra- 
cional, também valem os mesmos mecanismos de fuga do medo passivo; a diferença entre eles, no entanto, é que no medo ativo nós fugimos por não poder aniquilar-nos no desmaio. Portanto, na iminência da impossibilidade de resolver um problema através dos meios deterministas do mundo, a consciência estabelece uma conduta mágica que visa suprimir este objeto, porém essa supressão só se faz acompanhada da própria supressão da consciência. O medo é uma consciência que visa negar os objetos do mundo exterior mesmo que para isso ela própria deva aniquilar-se (desmaiar). Doravante, o desmaio propiciado pela conduta emocional da fuga é representado, é uma conduta mágica que visa negar o objeto perigoso utilizando todo o nosso corpo para esta finalidade e alterando "a estrutural vetorial do espaço onde vivemos ao criar uma direção potencial, do outro lado" (SARTRE, 1995, p. 85). A partir de tudo isso:

A conduta emocional pode ser compreendida como uma maneira de conjurar a possibilidade para a consciência se afastar, bruscamente, de sua situação. Certamente, ela irrealiza as exigências pragmáticas da situação no seio da qual ela se emprega, mas não se tornando indiferente a tal situação. Se a emoção é definida como fuga, ela é uma fuga in loco, uma fuga que permanece ligada aquilo do qual ela é a fuga (GELY, 2012, p. 313).

No desenrolar-se do texto, Sartre ainda segue analisando outras emoções através das lentes da "reflexão eidética", lentes que desvelam a essência finalista da consciência emocional: procurando compreender a tristeza passiva, o filósofo empregará os mesmos termos da conduta mágica que assola a consciência diante dos meios deterministas do mundo. $\mathrm{Na}$ tristeza, observamos o isolamento e a apatia com a qual o sujeito se apresenta diante de seus afazeres e diante de outras pessoas. Antes de almejar a solidão, tal atitude revela a mudança estrutural do mundo operada por uma consciência emotiva. Não obstante, tendo perdido uma das condições ordinárias de sua ação no mundo, o indivíduo ainda continua sendo constrangido pelo mundo a agir. Assim, a tristeza passiva é uma tentativa da consciência em "transformar a estrutura do mundo substituindo sua constituição presente por uma estrutura totalmente indiferenciada. Trata-se de fazer do mundo uma re- 
alidade afetivamente neutra (...)" (SARTRE, 1995, p. 86). Em outras palavras, a tristeza passiva é também uma fuga diante dos caminhos sulcados pelas vias deterministas e objetivas do mundo, uma mudança estrutural desses caminhos em busca de novas direções. Acuado e acolhido em um canto sombrio, o sujeito almeja, com todas as forças, escapar das dificuldades desse mundo ao conferir-lhe uma monotonia e uma indiferença. Deste fato emanam os comportamentos daquele que sofre uma tristeza: o isolamento na penumbra, a solidão de um quarto à multidão, o silêncio ao invés do barulho, etc. Enfim, a consciência, insuflada pela perda de uma de suas condições ordinárias para sua ação no mundo, busca (magicamente) transformar o mundo em mundo indiferente e sombrio para, com isso, justificar sua inação.

O esquema sartreano da atitude da consciência emotiva diante do mundo se estende também à tristeza ativa; vejamo -la. A paciente de Janet deseja confessar-lhe algo. Todavia, ela chora e soluça, utiliza seu corpo para levar o psicólogo a uma atitude de atenção afetuosa. Através desses gestos, ela põe fora de alcance a confissão a ser realizada; "enquanto estiver possuída pelas lágrimas e os soluções, toda possibilidade de falar é-lhe tirada" (SARTRE, 1995, p. 88). Ela chora e soluça precisamente para nada dizer, deixa a potencialidade do ato em suspenso para livrar-se da liberdade que possuía em relação a este ato. Aliás, façamos notar aqui que a liberdade da consciência entre em conflito com as estruturas organizadas e deterministas do mundo: ora, se não houve esta liberdade (enquanto intencionalidade, isto é, enquanto movimento de transcendência) que atravessa a consciência de ponta a ponta, a análise de Sartre não poderia referir-se à conduta emotiva como uma conduta mágica realizada pela própria consciência, pois o sentido do mágico indica, então, que é a própria consciência que altera a si mesma para alterar, na sequência, o mundo que a cerca. Nesta toada, o filósofo pode referir-se a crise emocional da paciente de Janet como "abandono de responsabilidade", como uma comédia mágica. A partir disso, deve-se admitir que a emoção é um fenômeno galvanizado pela liberdade eidética da consciência: só há transformação mágica do mundo porque a consciência é 
livre para operá-la. Eis precisamente aqui o ponto nevrálgico a ser explicitado: se o mundo é mundo determinado, isso não significa que a consciência não possa, ainda que magicamente (no nível fenomênico), alterá-lo (daí que não possamos falar em passividade da consciência diante deste mundo difícil).

Realizadas as explanações acerca do medo e da tristeza, ainda seria necessário aclimatar psicofenomenologicamente a alegria. Ora, olhando-a desatentamente, poderíamos incorrer no erro de não considerá-la como uma conduta mágica, pois o sujeito alegre, ao que tudo indica, não precisa se defender contra nenhuma ameaça e nem realizar nenhuma modificação fenomênica. No entanto, Sartre é enfático ao dizer que a alegria é também uma conduta mágica porque "tende a realizar por encantamento a posse do objeto desejado como totalidade instantânea" (SARTRE, 1995, p. 91). N'outros termos, ela busca antecipar essa posse, lança-se no futuro para possuir o objeto, de uma só vez, no presente. A estrutura de transformação do mundo também reaparece neste caso: nas gesticulações corporais da pessoa alegre (dançar, cantar de alegria, pular, etc.) nós somos capazes de desvelá-las como gesticulações que almejam possuir simbolicamente o objeto. Exemplo: deverei receber a visita da pessoa amada. Antes mesmo de ela chegar, eu danço, canto alegremente, isto é, eu opero uma modificação magica do mundo de modo que esta pessoa figure como a única qualidade do mundo e me seja dada antes mesmo de encontrá-la.

\section{A crença e corpo perturbado da consciência emoti- va: considerações finais}

A emoção, em todos os casos analisados, revelou-se como um fenômeno de consciência cuja finalidade - estrutura funcional - é a transformação do mundo em mundo mágico utilizando nosso corpo como meio de encantamento, de materialização do psíquico fenomênico. Através dessa perspectiva fenomenológica, somos levados a reafirmar que só podemos compreender o fenômeno emotivo se estivermos persuadidos de sua estrutura funcional, de seu caráter finalista e, não sem primazia, da crença que galvaniza a consciência emocionada. 
Ademais, a crença estabelece a verdadeira emoção da falsa emoção. Nas emoções falsas, as condutas não são sustentadas por algo, elas existem sozinhas e são voluntárias, "orientamos magicamente certas qualidades para objetos verdadeiros. Mas essas qualidades são falsas" (SARTRE, 1995, p. 95). Ao contrário desta, no verdadeiro fenômeno emotivo, o homem emocionado percebe as qualidades intencionadas para os objetos como qualidades verdadeiras. A consciência crê que as qualidades intencionadas por ela no objeto visado são realmente verdadeiras, fazendo com que a emoção seja sofrida. Por conseguinte, não podemos sair dela voluntariamente, não podemos interrompê-la a nosso bel prazer. Por ser sofrida, a emoção designa o aspecto radical da espontaneidade da consciência, ela assevera essa liberdade da qual não detemos o controle. É necessário salientar ainda que a verdadeira emoção deverá mostra-se através de um corpo perturbado no qual a conduta constitui sua forma e significação. O filósofo novamente:

Para que nós apreendamos verdadeiramente o horrível, não basta apenas imitá-lo, é preciso que nós sejamos enfeitiçados, excedidos por nossa própria emoção, é preciso que o quadro formal da conduta seja preenchido por qualquer coisa de opaco e de pesado que lhe serve de matéria. Compreendemos aqui o papel dos fenômenos puramente fisiológicos: eles representam o sério da emoção, são fenômenos de crença. Certamente eles não devem ser separados da conduta: em primeiro lugar, eles apresentam uma certa analogia com ela. (...) eles (os fenômenos fisiológicos) compõem com a conduta uma forma sintética total e não poderiam ser estudados por si mesmos (...). Então, é preciso considerar que a emoção não é simplesmente representada, não é um comportamento puro, é o comportamento de um corpo que está em um certo estado: o estado sozinho não provocaria o comportamento, o comportamento sem o estado é comédia; mas a emoção aparece em um corpo perturbado que mantém uma certa conduta. A perturbação pode sobreviver sem à conduta, mas a conduta constitui a forma e a significação da perturbação. De outro modo, sem essa perturbação a conduta seria significação pura, esquema afetivo (SARTRE, 1995, p. 97-98).

Encontramo-nos diante de uma relação fundamental para o advir da emoção, qual seja: o estado acompanhado da conduta. A emoção - variação eidética da consciência -, expressa-se, concretiza-se pelo itinerário de um corpo em um determinado estado (perturbado) e que mantém uma determinada conduta 
que constitui a forma e a significação desta perturbação. Esta sintaxe entre conduta e estado arquiteta o que poderíamos denominar de forma sintética, afinal, como lemos acima, a conduta fomenta a forma e a significação da perturbação, mas sem ela, esta conduta seria apenas um esquema afetivo. Ambos - conduta e estado -fazem com que a consciência adira às condutas mágicas, pois "para crer nas condutas mágicas, é preciso estar perturbado" (SARTRE, 1995, p. 98). Assim, seguindo o expediente da forma sintética tecida entre a conduta e o estado, podemos explanar o sentido fenomenológico da emoção como fenômeno de crença de uma consciência e de um corpo perturbado. Acerca deste sentido, é intrínseco que consideremos as relações da consciência com o mundo, mas também convém lembrar a característica dupla do corpo nos termos de Esquisse.

De um lado, objeto no mundo, de outro, a experiência vivida imediata da consciência, o corpo é inexoravelmente uma das condições para o irromper do fenômeno emotivo. Se o corpo, tal como este aparecia no Essai, havia sido privado da relação íntima com a consciência (justamente porque lá se tratava de examinar as potências do campo transcendental puro e impessoal), aqui, embora Sartre não esteja amplamente preocupado em tematizar as relações dele com a consciência, acreditamos ser forçoso admitir que, pelo menos, o corpo é preponderante neste novo cenário teórico (psicologia fenomenológica): ele ganha uma dimensão existencial, pois é este corpo perturbado que pode sinalizar e distinguir, junto da crença, a verdadeira da falsa emoção. Façamo-nos entender. Se a crença é um dispositivo constitutivo na fundamentação da verdadeira emoção, ela só se faz assim quando há um corpo perturbado que é perpassado pela conduta. Portanto, é o corpo perturbado que materializa, exterioriza a emoção de uma consciência que crê nas condutas mágicas diante de um mundo tornado mágico. Destarte, os fenômenos fisiológicos representam o sério da emoção, são fenômenos de crença onde caberá à conduta constituir sua forma e sua significação. No entanto, sem a perturbação, a conduta seria tão somente um esquema afetivo, significação pura, comédia. 
Na verdadeira emoção, o corpo é solicitado como meio de encantamento do mundo: a modificação da consciência para modificar o mundo leva, na sequência, a uma modificação do corpo como totalidade sintética para que ela possa viver esse mundo novo através deste corpo perturbado. N'outros termos, diremos que o corpo realiza o preenchimento material da emoção, o corpo perturbado é o expediente de materialização do fenômeno emotivo, "a crença vivida da consciência, enquanto ela é vista do exterior" (SARTRE, 1995, p. 100). Gostaríamos de insistir que o fenômeno emotivo, por mais que amplie os territórios do corpo, deve sua maior compreensão aos mecanismos fundantes da consciência irrefletida e não tética: mas isso não significa, de modo algum, que o corpo esteja totalmente submetido aos poderes da consciência (daí que uma leitura que subsuma uma simples subordinação do corpo à consciência seja uma leitura simplista).

Resumo da ópera: na fundamentação da emoção, localizamos uma tripla transformação: a da consciência, a do corpo e a do mundo. Se na Introdução de Esquisse, Sartre comentava as necessidades de analisarmos as totalidades sintéticas mundo e homem e a significação da essência emotiva, estas necessidades tornam-se mais claras quando, ao longo deste artigo, assinalamos a interdependência entre a consciência, o corpo e o mundo para a constituição do fenômeno emotivo. Assim, esses dois conceitos - totalidade sintética \& significação - remetem um ao outro, entrelaçam-se, são operadores da realidade humana; o fazer-se da psicologia fenomenológica deve, obrigatoriamente, passar pela investigação de tais conceitos elementares porque postula, no início de suas investigações, a pergunta eidética: "o que deve ser uma consciência para que ela seja capaz de se emocionar".

\section{Referências}

CABESTAN, Philippe. Lêtre et la conscience: Recherches sur la psychologie et l'ontophénoménologie sartriennes. Paris: Éditions OUSIA, 2004.

COOREBYTER, Vincent de. Sartre face à la phénoménologie: Autour de "Lintentionnalité" et "La transcendance de Lego". Bruxelles: Éditions OUSIA, 2000. 
COOREBYTER, Vincent de. "Le corps et l'aporie du cynisme dans L'esquisse d'une théorie des émotions"; in: Bulletin d'analyse phénoménologique, VIII, 1. Belgique: 2012, p. 273-285.

GÉLY, Raphael. "Émotion, imagination, incarnation: Réflexion à partir de l'Esquisse d'une théorie des emotions"; in: Bulletin d'analyse phénoménologique, VIII, 1. Belgique: 2012, p. 303-429.

HUSSERL, Edmund. Ideias para uma fenomenologia pura e para uma filosofia fenomenológica. Introdução geral à fenomenologia pura. Tradução de Marcio Suzuki, prefácio de Carlos Alberto Ribeiro de Moura, São Paulo: Ed. Idéias e Letras, 2006.

JEASON, Francis. Le problème moral et la pensée de Sartre. Paris: Editions du Seuil, 1965.

JANICAUD, Dominique. Heidegger en France. Paris: Hachette Littérature, 2001.

MOUILLE, Jean-Marc. Sartre: Conscience, ego et psyche. Paris: PUF, 2000.

MOUTINHO, Luiz Damon dos Santos. Sartre: psicologia e fenomenologia. São Paulo: Ed. Brasilience, 1995.

SARTRE, Jean-Paul. La transcendance de l'ego et autres textes phénoménologiques. Texte introduits et annotés par V. de Coorebyter. Paris: J. Vrin, 2003.

SARTRE, Jean-Paul. "Une idée fondamentale de la phénoménologie de Husserl: l'intentionnalité", in: Sartre, La transcendance de l'Ego et autres textes phénoménologiques. Texte introduits et annotés par V. de Coorebyter. Paris: J. Vrin, 2003.

SARTRE, Jean-Paul. Esquisse d'une théorie des émotions. Paris: HERMANN, 1995.

SARTRE, Jean-Paul. Diário de uma Guerra Estranha. Tradução de Aulyde Soares Rodrigues e Guilherme João de Freitas Teixeira. Rio de Janeiro: Editora Nova Fronteira, 2005.

THOMÈS, Arnaud. "Sartre et la critique des fondements de la psychologie: Quelques piste sur les apports de Sartre et de Politzer"; in: Bulletin d'analyse phénoménologique, VIII, 1. Belgique: 2012, p. 223-244.

THOMÈS, Arnaud. "Préface à L'Esquisse d'une théorie des émotions"; in: Esquisse d'une théorie des émotions. Paris: Hermann, 2010.

WORMS, Frédéric. La philosophie en France au XXième siècle: moments. Paris: Gallimard, 2009. 